\title{
FIRST IDENTIFICATION OF HOUSE FINCHES IN WEYBURN
}

RAY A. BELANGER, 412 McGillivray Drive, Weyburn, Saskatchewan. S4H $1 \mathrm{M} 1$

In early December 1992 I was contacted about the presence of three unidentified birds at 47 Prairie Avenue in Weyburn, Saskatchewan. This location, the home of Leo and Sophie Belanger, is an active winter bird gathering spot made possible by an extensive feeding program.

The description of one bird in particular caused me to suggest House Finch to Belanger, who at the time was somewhat mystified about its identification. During the same period he reported the existence of three Pine Siskins at his feeding stations. The consensus of Belanger and others, who had not yet observed the birds in question, was that it surely must have been a Purple Finch. They arrived at this decision because of the bird's coloration which was described as being red in the head and breast areas. The fact that the Purple Finch is a regular, if not a common, visitor further substantiated that position.

On 27 December, I accompanied Bob Luterbach of Prince Albert to the Prairie Avenue feeders in hopes of picking up new species for the Christmas Bird Count. Two finch-like birds were foraging at one of the feeder stations. Without field glasses, they resembled large Pine Siskins. Luterbach immediately identified one of the birds as being a female House Finch. This deduction was spurred on by the fact that the bird displayed a paler and less pro- nounced facial pattern than the Purple Finch. Its underparts were white with definite streaking, while its back showed a grey-brown coloration. The female Purple Finch, on the other hand, displays a distinct facial pattern, with a pale line over the eye and a dark stripe below a dark cheek. $^{2}$ The second bird was found to be an immature House Finch.

A few minutes after the identification of the first two members of the species, the male House Finch made its appearance. It showed a bright orange-red forehead, breast and rump, with a brownish back, a stripe over the eye and dark streaks on the side and underparts. It differed from the male Purple Finch, which displays a more raspberry coloration and a body which is void of side and belly streaks. The birds were observed for approximately five minutes before they departed. Over the next few days, the Belangers, Luterbach, Greg Bobbitt, Nick Postey, and Chuck Hodgson observed the birds on at least four separate occasions. Leo Belanger admitted that the birds which he had thought to be Pine Siskins were indeed the House Finches witnessed at the later date. Photographs of the House Finches were taken by $\mathrm{Be}-$ langer and Mabel Charlton.

The House Finch, unlike the House Sparrow, is a North American bird. Originally a west coast native, its expansion has been unusual. In 
the 1940s an illegal shipment of House Finches from California, destined for the bird cages of New York City, was seized and the birds were released. ${ }^{3}$ Since that time the House Finch population has exploded and numbers in some areas exceed those of the ever-present House Sparrow. As of October 1990, 11 sightings of the House Finch had been recorded for the province. ${ }^{1}$ Whether its arrival is from the east or west is speculation. Its appearance in Weyburn and other parts of Saskatchewan, however, is a premoni- tion of the influx which seems destined to occur.

1. KREBA, ROBERT, compiler. 1990. Field checklist of Saskatchewan birds. Saskatchewan Natural History Society/Museum of Natural History/ Canadian Wildlife Service.

2. RANSOM, J.E. 1981. Grosbeaks, Finches, Sparrows, Longspurs, Buntings. In Complete field guide to North American wildlife, Harper and Row, New York, p. 243.

3. TERRES, K. 1980. The Audubon Society encyclopedia of North American birds. Alfred A. Knoff, New York, p. 302.

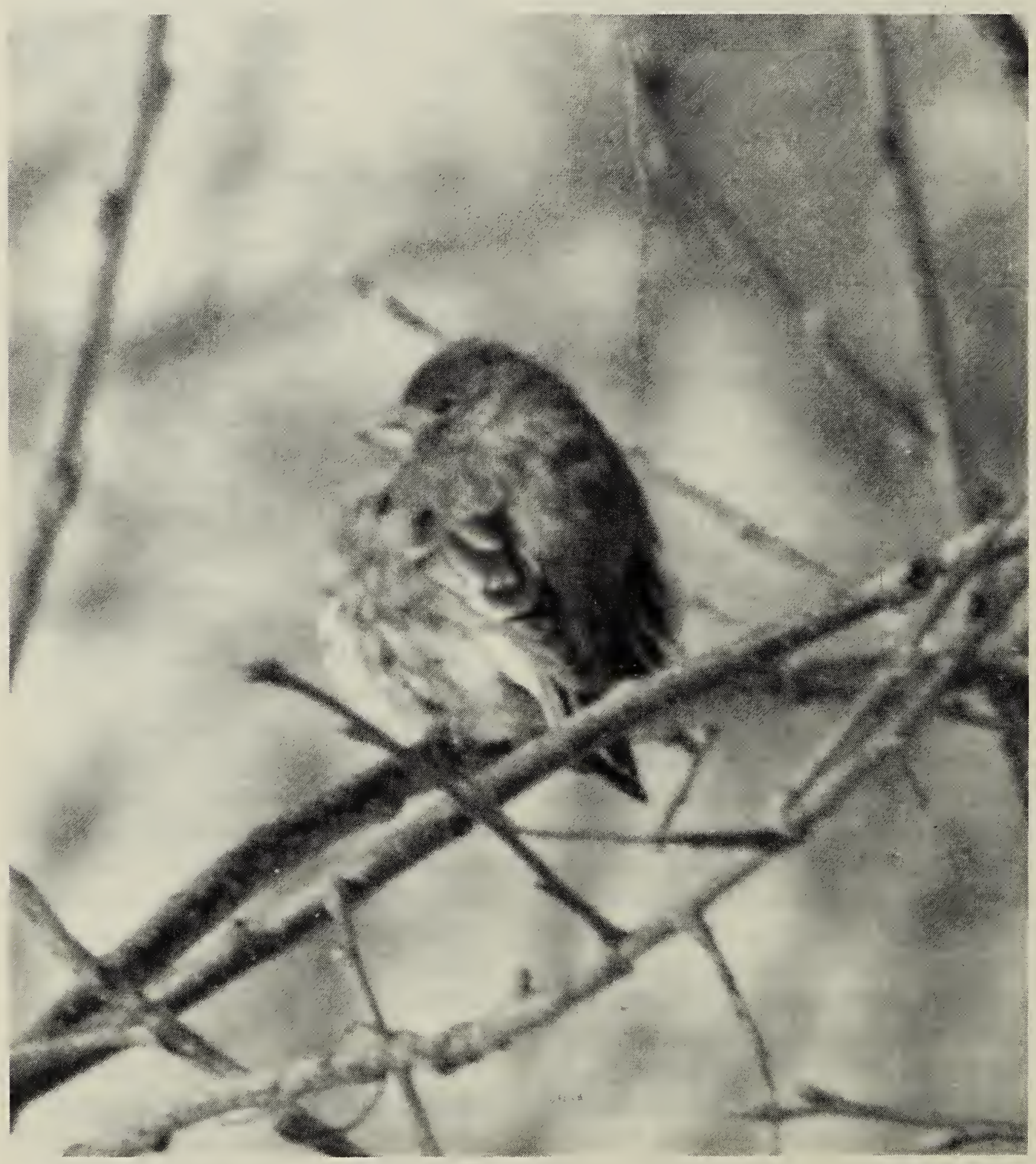

